\title{
Scientists urged to protest against new 'book burners'
}

(NASA) and originally a Republican nominee, has appointed minorities in key positions in NASA for the first time. Addressing the Atlanta meeting, he pledged to involve more "capable women and quality minority scientists" in the work of the notoriously white and male agency.

Yet President Bill Clinton's attempts to appoint a more diverse administration have attracted much derision in the United States, and were almost certainly a factor in last November's elections, when Republicans won almost two-thirds of the white male vote.

Ayala maintains that this derision does not permeate the scientific community. "There is a backlash among the general population, but not among people who practice science," he says. He cites election results to the 11-strong board of the AAAS - which has four women, two blacks, and the Spanish-born Ayala as president - as evidence of members' desire for diversity.

Wyche does not see a backlash on the campuses either. But he fears for the future of racial diversity in science in the United States if the federal government decides to stop pushing for it.

"We have slowly built up support for what we are doing among the majority [white] faculty over the past 20 years. They have supported us because of the protection of the federal government." Without that protection, he fears, that "fragile base of support" will fade away.

Colin Macilwain
Atlanta. Branding the new leadership of Congress as "book burners", Bruce Babbitt, the Secretary of the Interior, last week called on scientists to rally in defence of three science agencies in his department the US Geological Survey (USGS), the Bureau of Mines and the National Biological Survey (NBS) - all of which, he predicted, Congress would try to close down before the end of this year.

In a combative address to the AAAS meeting in Atlanta which marked a further hardening of the administration's opposition to Republican plans to cut the budget, Babbitt said that the elimination of the three agencies threatened to "eliminate root-andbranch every trace of science" from his department.

"The proposed destruction of these agencies is the [natural] resource equivalent of book burning," said Babbitt. He also compared proposals to close the USGS in the wake of last year's earthquake in California to "the burning of a few more heretics at the stake" after an earthquake in seventeenthcentury Portugal.

But he described the threat to the agencies as "genuine and immediate", predicting that, in the autumn, President Bill Clinton

\section{R\&D funding 'heading for $25 \%$ cut'}

Atlanta. Spending by the US government on research and development (R\&D) is likely to fall by a quarter over the next five years, according to George Brown, former chairman and now senior Democrat on the newly-named House of Representatives Science Committee.

The veteran California congressman told a AAAS session on the future of the physical sciences that the impact of Republican spending plans on science is hard to gauge. But he added: "my own prediction is for a 25 per cent cut in total R\&D spending over the next five years, with some areas suffering even more."

Brown conceded that he had been among those who had encouraged scientists to link their work to "national goals" which had now changed with the Republican takeover of Congress. This, he said, had left the scientific community in "the worst situation"; it was now under fiscal attack, but without the benefit of goals and performance standards, and being judged by "inappropriate measures".

As a result, Brown predicted, basic research with now be worse off than before, isolated by the impending decline in applied research while being subject to new political demands. "Putting on my partisan hat, it is naive to think that research, [whether] might be unable to veto a budget bill that would close them down. Furthermore, if Clinton does indeed veto the budget bills, Republicans in Congress have pledged to withdraw all approval for federal spending - even if this means that parts of the government have to close down.

The proposal to close all three agencies is included in a list of cuts prepared by Republican members of the House Budget Committee last April. The list is referred to in the Contract with America, the Republican election manifesto, as an example of how savings could be made. But Republicans deny that the specific cuts form part of the Contract.

[Robert Walker (Republican, Pennsylvania), chairman of the House Science Committee and vice-chair of the Budget Committee, told a closed meeting of senior scientists in Washington last week that elimination of the USGS was 'off the list' of Republican cuts.

At the time of going to press, no-one in Walker's office was available to confirm his comments. Bonnie McGregor, deputy director of the survey, said she was unaware of them, and warned against complacency in the run-up to appropriations hearings due to start next week.]

Of the three science agencies at the Interior Department, the most seriously threatened is the NBS, recently and defensively renamed the National Biological Service. But some officials say that Babbitt himself took a risk by setting up the NBS in 1993 as a politically contentious consolidation of several previously obscure research divisions within his department.

The threat to the survival of the NBS has left natural resource sciences such as conservation biology and ecology in disarray. Researchers had been expecting that, after the foundation of the survey, Babbitt would start to provide it with money to fund the collection of badly needed data; officials now concede that this will not happen.

Instead, they expect Congress to attempt to rescind part of the $\$ 167$ million already appropriated to NBS for the current year, before moving on to more drastic measures. "I'm just a simple university professor suddenly thrown into the world of Washington," protests $\mathrm{H}$. Ronald Pulliam, the director of the NBS, who happily held a tenured post at the University of Georgia until last summer.

Pulliam says that good science at NBS need not necessarily lead to a new outbreak of regulation that Republicans claim to fear. "The more we know about natural systems, the more chance there is that we can have the economic progress we want, without losing the biological diversity we need," says Pulliam.

Colin Macilwain 